\title{
Feto-maternal outcomes in HIV positive pregnant women: Pakistan PPTCT experience
}

\author{
Shazra Abbas', Naveeda Shabbir \\ From $16^{\text {th }}$ International Symposium on HIV and Emerging Infectious Diseases \\ Marseille, France. 24-26 March 2010
}

\section{Background}

To determine the feto-maternal outcomes in sero-positive pregnant women.

\section{Methods}

\section{Study population}

All HIV positive pregnant women referred to seven PPTCT (Prevention of Parent-to-Child Transmission) Centers of Pakistan.

\section{Study time}

March 2007-Oct 2009.

\section{Study design}

Descriptive study.

During the study period, thirty seven HIV positive pregnant women were referred to PPTCT Centers for antenatal care and delivery. All women were given ARV prophylaxis $(\mathrm{CD} 4>350 \mathrm{~mm})$ or HAART $(\mathrm{CD} 4<350 \mathrm{~mm})$ and AFASS criteria was used to select a safer infant feeding option. Outcomes in terms of pregnancy complications, mode of delivery and peri-natal transmission of HIV are observed.

\section{Results}

Among thirty seven women registered with PPTCT centres, thirty delivered at term. Mean gestational age at time of delivery was 39 weeks. Two women had miscarriages at nineteen and twenty one week. Five women have ongoing pregnancies. The preferred mode of delivery at hospital was caesarean section. Through AFASS, twenty eight women opted for formula milk for their babies while two opted exclusive breast feeding. Twenty three babies tested, so far, with HIV PCR viral load

\footnotetext{
* Correspondence: shazraabbas@gmail.com

National AIDS Control Program Pakistan, Islamabad, Pakistan
}

were negative, showing effectiveness of PPTCT interventions.

\section{Conclusion}

Though Pakistan has limited PPTCT experience, availability of ARVs and AFASS criteria has proved quite effective, giving hope to people living with HIV (PLHIV) to wish for and have HIV negative babies.

Published: 11 May 2010

doi:10.1186/1742-4690-7-S1-P134

Cite this article as: Abbas and Shabbir: Feto-maternal outcomes in HIV positive pregnant women: Pakistan PPTCT experience. Retrovirology 2010 7(Suppl 1):P134.

\section{Submit your next manuscript to BioMed Central and take full advantage of: \\ - Convenient online submission \\ - Thorough peer review \\ - No space constraints or color figure charges \\ - Immediate publication on acceptance \\ - Inclusion in PubMed, CAS, Scopus and Google Scholar \\ - Research which is freely available for redistribution

